Nama : Annisa Nurfadillah

Nim : 70200120035

Kelas : B

\title{
KEBUTUHAN ENERGI GIZI DALAM TUBUH
}

\section{Kebutuhan Energi dan Protein}

\section{Energi}

Tubuh memerlukan energi sebagai sumber tenaga untuk segala aktivitas. Energi diperoleh dari makanan sehari-hari yang terdiri dari berbagai zat gizi terutama karbohidrat dan lemak. Energi yang dipergunakan untuk melakukan pekerjaan, dilepaskan dalam tubuh pada proses pembakaran zat-zat makanan. Dengan mengukur jumlah energi yang dikeluarkan itu dapat diketahui berapa banyak makanan yang diperlukan untuk menghasilkannya (Soediaoetama,2000).Kebutuhan energi seseorang adalah konsumsi energi dari makanan yang diperlukan untuk menutupi pengeluaran energi seseorang bila ia mempunyai ukuran dan komposisi tubuh dengan aktivitas yang sesuai dengan kesehatan jangka panjang dan yang memungkinkan pemeliharaan aktivitas fisik yang dibutuhkan secara sosial dan ekonomi (Beck,1993 dan Almatsier, 2001).

Sumber energi adalah bahan makanan sumber lemak, seperti lemak dan minyak, kacangkacangan dan biji-bijian. Selain itu bahan makanan sumber karbohidrat, seperti padi-padian, umbi-umbian dan gula murni.Hasil kajian menunjukkan kisaran distribusi energi gizi makro dari pola konsumsi penduduk Indonesia berdasarkan analisis data Riskesdas 2010 adalah 9-14\% energi protein, 24-36\% energi lemak, dan 54-63\% energi karbohidrat Yang belum sebaik yang diharapkan, Yaitu 5-15\% energi protein, 25-55\% energi lemak, dan 40-60\% energi karbohidrat tergantung usia atau tahap tumbuh kembang. (IOM, 2005)

\section{Protein}

Protein merupakan zat gizi yang sangat penting karena yang paling erat hubunganya dengan proses-proses kehidupan dan protein menyediakan bahan bahan yang penting peranannya untuk pertumbuhan serta pemeliharaan jaringan tubuh. Protein adalah zat makanan yang mengandung protein. Secara praktis dapat dikatakan bahwa hampir semua sumber nitrogen dalam makanan sehari-hari adalah protein. Protein dalam tubuh mempunyai fungsi antara lain untuk pertumbuhan dan pemeliharaan, untuk pembantukan ikatan-ikatan essensial tubuh,mengatur keseimbangan air, memelihara netralitas tubuh, pembentukan 
antibodi dan mengangkat zat-zat gizi.Sumber protein bisa berasal dari bahan makanan hewani maupun bahan makanan nabati. Bahan makanan hewani merupakan sumber protein yang baik, dalam jumlah maupun mutu, seperti telur, susu, daging, unggas, ikan dan kerang. Sumber protein nabati adalah kacaang kedelai, dan hasilnya, seperti tempe, dan tahu serta kacangkacangan lainnya (Almatsier, 2001).

Kebutuhan protein menurut FAO/WHO/UNU (2000) adalah konsumsi yang diperlukan untuk mencegah kehilangan protein tubuh dan memungkinkan produksi protein yang diperlukan dalam massa pertumbuhan, kehamilan atau menyusui. Jumlah protein yang diperlukan oleh tubuh seseorang tergantung dari banyaknya jaringan aktif, makin besar dan berat organ tersebut makin banyak jaringan aktif sehingga makin banyak pula protein yang diperlukan untuk mempertahankan atau memelihara jaringan itu. (Soediatama, 2000)

\section{Kebutuhan Gizi Ibu Hamil}

seorang ibu yang sedang hamil, kita akan pelajari bagaimana dengan kebutuhan gizi ibu hamil agar kehamilan dapat optimal. Dalam setiap harinya, ibu hamil dianjurkan untuk menambah zat gizi dibanding kondisi normal. Energi tambahan bagi ibu hamil (bumil) pada trimester (TM) II dibutuhkan untuk; pemekaran jaringan ibu yaitu penambahan volume darah, pertumbuhan uterus dan payudara serta penumpukan lemak. Sepanjang trimester III, energi tambahan dipergunakan untuk pertumbuhan janin dan placenta. Gizi berpengaruh terhadap kesehatan dan daya tahan tubuh ibu hamil, baik sebelum maupun ketika sedang hamil. Sedangkan bagi bayi; status gizi janin yang dilahirkan dari ibu dengan malnutrisi sebelum hamil atau selama minggu pertama kehamilan cenderung akan melahirkan bayi yang menderita kerusakan otak dan sumsum tulang karena sistem syaraf pusat sangat peka pada 2-5 minggu pertama kehamilan. Ibu penderita atau mengalami malnutrisi sepanjang minggu terakhir kehamilan akan melahirkan bayi dengan berat badan lahir rendah. Faktor yang mempengaruhi status gizi ibu sewaktu konsepsi terdiri dari : keadaan sosial dan ekonomi ibu sebelum hamil; keadaan kesehatan dan gizi ibu; jarak kelahiran jika yang dikandung bukan anak pertama; paritas; dan usia kehamilan pertama. Sedangkan status gizi ibu pada waktu melahirkan dipengaruhi : keadaan sosial dan ekonomi ibu waktu hamil; derajat pekerjaan fisik; asupan pangan; pernah tidaknya terjangkit penyakit infeksi. Perlu diingat adalah status gizi ibu ketika hamil dan melahirkan akan mempengaruhi gizi anaknya. Makanan bumil sebaiknya disesuaikan dengan keluhan yang dialami, seperti pada Trimester l; nafsu makan menurun, rasa mual dan muntah sebaiknya diberikan makanan kering dan tinggi karbohidrat, serta buah-buahan, selanjutnya pada Trimester II; kebutuhan kalori mulai meningkat, Berat badan mulai bertambah, pada masa ini sebaiknya diberikan makanan seimbang, banyak buah dan sayur,sedangkan pada Trimester III nafsu makan baik sehingga makanan diberikan porsi kecil tapi sering, banyak buah dan sayur .

Banyak hal-hal yang harus dipertimbangkan pada saat menyusun menu seimbang bagi ibu hamil yaitu : perhatikan kebutuhan energi dan zat gizi, khususnya protein, Fe, vitamin $\mathrm{C}$, calsium; 
pemilihan jenis bahan makanan dan pengolahannya sesuaikan dengan keluhan ibu; bentuk dan frekuensi makan disesuaikan dengan keluhan ibu. Faktor yang mempengaruhi hasil kehamilan meliputi asupan zat gizi makanan ibu; status gizi prahamil; pertambahan berat badan selama hamil; kondisi ibu pada masa remaja (masih dalam proses pertumbuhan); jumlah janin per kehamilan; gizi kurang saat pra hamil dan kurang asupan selama hamil berisiko terjadinya abortus, stillbirth, dan berat bayi lahir rendah (BBLR); Obesitas menyebabkan kesulitan untuk hamil, risiko hipertensi selama kehamilan dan berisiko diabetes gestasional ( diabetes yang dipicu oleh adanya kehamilan). Tambahan energi yang dibutuhkan ibu hamil usia dewasa dengan status gizi baik pada saat pra hamil, serta aktivitas fisik ringan untuk trimester I hampir tidak diperlukan energi tambahan, trimester II dibutuhkan 300-350 kkal/hari, dan trimester III dibutuhkan tambahan energi sebesar 450-500 kkal/hari.

\section{Kebutuhan Kalori}

Ibu yang sedang hamil membutuhkan tambahan energi/kalori untuk tumbuh kembang janin, plasenta, jaringan payudara, cadangan lemak, serta untuk perubahan metabolisme yang terjadi. Pada trimester II dan III, kebutuhan kalori tambahan ini berkisar 300 kalori per hari dibanding saat tidak hamil. Berdasarkan perhitungan, pada akhir kehamilan dibutuhkan sekitar 80.000 kalori lebih banyak dari kebutuhan kalori sebelum hamil. Karbohidrat merupakan sumber utama untuk tambahan kalori yang dibutuhkan selama kehamilan. Tumbuh kembang janin selama dalam kandungan membutuhkan karbohidrat sebagai sumber kalori utama. Pilihan yang dianjurkan adalah karbohidrat kompleks seperti roti, serealia, nasi dan pasta. Selain mengandung vitamin dan mineral, karbohidrat kompleks juga meningkatkan asupan serat yang dianjurkan selama hamil untuk mencegah terjadinya konstipasi atau sulit buang air besar dan wasir.

\section{Kebutuhan Protein}

Kebutuhan protein bagi wanita hamil adalah sekitar 60 gram per hari. Artinya, wanita hamil butuh protein 10-15 gram lebih tinggi dari kebutuhan wanita yang tidak hamil. Protein tersebut dibutuhkan untuk membentuk jaringan baru, maupun plasenta dan janin. Protein juga dibutuhkan untuk mendukung pertumbuhan dan diferensiasi sel.

\section{Lemak}

Lemak merupakan sumber tenaga yang vital dan untuk pertumbuhan jaringan plasenta. Pada kehamilan yg normal, kadar lemak dalam aliran darah akan meningkat pada akhir trimester III. Tubuh wanita hamil juga menyimpan lemak yg akan mendukung persiapannya untuk menyusui setelah bayi lahir.

\section{Kebutuhan Vitamin dan Mineral}

Kebutuhan meningkat dibanding sebelum hamil, untuk mendukung tumbuh kembang janin serta proses diferensiasi sel. Tambahan zat gizi lain yang penting juga dibutuhkan untuk membantu 
proses metabolisme energi seperti vitamin (Vit) B1, vit B2, niasin, dan asam pantotenat, Vit B6 dan B12 diperlukan untuk membentuk DNA (Deoxyribonucleic Acid) dan sel-sel darah merah, sedangkan Vit B6 juga berperan penting dalam metabolisme asam amino. Kebutuhan vit $A$ dan $\mathrm{C}$ juga meningkat selama hamil. Begitu juga kebutuhan mineral, terutama $\mathrm{Mg}$ (magnesium) dan $\mathrm{Fe}$ (zat besi). Mg dibutuhkan untuk mendukung pertumbuhan dari jaringan lunak. Sedangkan Fe dibutuhkan untuk membentuk sel darah merah dan sangat penting untuk pertumbuhan dan metabolisme energi, disamping untuk meminimalkan peluang terjadinya anemia. Kebutuhan zat besi menjadi dua kali lipat dibandingkan sebelum hamil.

Kebutuhan energi ibu hamil dapat dicari dengan menggunakan Metode Harrist Benedict kemudian hasilnya ditambah kalori rata-rata sesuai trimester kehamilan yaitu ditambah 180 kkal per hari pada Trimester I, dan ditambah 300 kkal per hari pada TM II \& TM III, Kebutuhan protein $: 1 \mathrm{gr} / \mathrm{kg} \mathrm{BB} /$ hari , Penambahan protein 17 gram mulai TM I s.d TM III, Kebutuhan lemak : 25$30 \%$ dari total kebutuhan energi

\section{Kebutuhan Gizi Ibu Menyusui}

Kebutuhan Nutrisi ibu menyusui meliputi Kebutuhan Energi, untuk memproduksi air susu ibu baru (ASI), ibu menyusui perlu tambahan energi yang bersumber dari 1) makanan sebesar 330 kkal pada enam $0 \mathrm{Kkal}$ pada enam bulan kedua. 2) 100-150 Kkal dari lemak cadangan tubuh ibu sendiri. Karena lemak tubuh dipakai maka BB ibu post partum turun 0,5 sampai dengan $1 \mathrm{~kg} /$ bulan . Kebutuhan Protein : Tambahan protein enam bulan pertama dan kedua sebesar $25 \mathrm{~g} /$ hari. Asupan lemak adalah 25-30 \% asupan energi , Asupan Karbohidrat kira-kira 160-200 g/hari. Kebutuhan vitamin ibu menyusui lebih besar dibandingkan ibu hamil kecuali vitamin D dan K. Ibu menyusui yang kekurangan vitamin menyebabkan vitamin ASI juga berkurang. Kebutuhan mineral ibu menyusui lebih besar dibandingkan dengan ibu hamil kecuali : $\mathrm{Ca}, \mathrm{P}, \mathrm{Mg}, \mathrm{F}$ dan Mo. Selama belum mengalami menstruasi pasca melahirkan kebutuhan Fe ibu lebih sedikit dari ibu yang tidak hamil. Kebutuhan air pada ibu menyusui bertambah sebanyak produksi ASI ( jadi sebaiknya ibu minum 1 gelas per kali menyusui). Sebaiknya ibu menyusui tidak minum kopi karena kopi bisa masuk melalui ASI yang menyebabkan bayi susah tidur. Hal-hal yang harus dihindari ibu menyusui antara lain : merokok; minum kopi; obat-obatan; radiasi. Perhitungan kebutuhan energi ibu menyusui menggunakan Metode Harrist Benedict, hasil yang didapatkan ditambah 500 kkal untuk 6 bulan pertama dan ditambah 550 kkal untuk 6 bulan kedua. Kebutuhan protein :1 gr/kg BB/ hari, ditambah 17 gram. Kebutuhan lemak : $25-30 \%$ dari total kebutuhan energi.

\section{Kebutuhan Gizi Bayi}

1. Formula Adaptasi 
Adapted berarti disesuaikan dengan kebutuhan bayi baru lahir. Formula adaptasi ini untuk bayi baru lahir sampai umur 6 bulan. Susunan formula adaptasi sangat mendekati susunan ASI dan sangat baik bagi bayi baru lahir sampai umur 4 bulan. Pada umur di bawah 3-4 bulan fungsi saluran pencernaan dan ginjal belum sempurna hingga pengganti ASI-nya harus mengandung zat-zat gizi yang mudah dicerna dan tidak mengandung mineral yang berlebihan. Komposisi yang dianjurkan oleh ESPGAN (1977) setelah bubuk formula tersebut dicairkan sesuai petunjuk prosedurnya.

\section{a. Lemak}

Kadar lemak disarankan antara 2,4-4,1 gr tiap $100 \mathrm{ml}$. Komposisi asam lemaknya harus sedemikian hingga bayi umur 1 bulan dapat menyerap sedikitnya 8,5\%. Disarankan juga bahwa 3-6 \% dari kandungan energi harus terdiri dari asam linoleat,

b. Protein

Kadar protein harus berkisar antara 1,2 dan 1,9 gr/100 ml dengan rasio whey/kasein $+60 / 40$ oleh karena kandungan protein pada formula ini relatif rendah (aminonya harus identik atau hampir identik dengan amino yang terdapat dalam protein ASI),

\section{Karbohidrat}

Disarankan untuk formula ini kandungan karbohidratnya antara 5,4 dan 8,2 gram tiap $100 \mathrm{ml}$. Dianjurkan supaya hampir seluruhnya memakai laktosa, selebihnya glukosa atau dekstrinmaltosa. Hal ini karena laktosa mudah dipecah menjadi glukosa dan galaktosa dengan bantuan enzim lactase yang sudah ada dalam mukosa saluran pencernaan sejak lahir. Laktosa juga merangsang pertumbuhan laktobasilus bificfus,

\section{d. Mineral}

Konsentrasi sebagian besar mineral dalam susu sapi seperti natrium, kalsium, fosfor, magnesium, dan klorida, lebih tinggi 3-4 kali dibandingkan dengan yang terdapat pada ASI. Pada pembuatan formula adaptasi kandungan berbagai mineral harus diturunkan hingga jumlahnya berkisar antara 0,25 dan 0,34 gram tiap $100 \mathrm{ml}$. kandungan mineral dalam susu formula adaptasi memang rendah dan mendekati yang terdapat pada ASI. Penurunan kadar mineral diperlukan oleh bayi karena dapat mengganggu keseimbangan air dan dehidrasi hipertonik

\section{Formula Awal Lengkap}

Berbeda dengan formula adaptasi, pada formula ini terdapat kadar protein yang lebih tinggi dan rasio antara fraksi-fraksi proteinnya tidak disesuaikan dengan rasio yang terdapat dalam susu ibu. Selain itu kadar sebagain mineralnya lebih tinggi dibandingkan dengan formula adaptasi. Keuntungan dari formula ini terletak pada harganya. Berhubung pembuatannya tidak begitu rumit maka ongkos pembuatannya juga lebih murah sehingga dapat dipasarkan dengan harga lebih rendah. Susu formula awal lengkap ini diberikan untuk bayi berusia 4-6 bulan. 


\section{Volume lanjutan}

pertumbuhan yang cepat dan aktifitas fisik yang meningkat maka dibutuhkan zat gizi yang dapat memenuhi kebutuhan bayi di atas 6 bulan. Pertumbuhan yang cepat memerlukan protein ekstra untuk perkembangan dan juga lebih banyak mineral. Formula lanjutan dapat diberikan pada anak dari usia 6 bulan - 3 tahun. Demikian tentang susu, berikutnya bila bayi sudah bisa mendapatkan makanan tambahan.

\section{Makanan Tambahan}

ASI dalam jumlah yang cukup memang merupakan makanan terbaik dan dapat memenuhi kebutuhan gizi bayi selama 4-6 bulan pertama. Namun, setelah umur 4 bulan bayi secara berangsur-angsur perlu diberikan makanan tambahan berupa sari buah atau buah buahan segar, makanan lumat, dan akhirnya makanan lembek.

\section{Kebutuhan Gizi pada Bayi}

Pemberian makanan tambahan sebagai makanan pendamping ASI harus disesuaikan dengan umur bayi karena itu alternatif pemenuhan gizi bayi pun disesuaikan dengan umur bayi.

\section{a. Gizi Bayi Usia 0 - 6 bulan.}

Dalam usia bayi 0-6 bulan, makanan yang paling tepat untuk bayi adalah air susu ibu atau ASI, karena memang komposisi zat gizi yang ada pada ASI paling tepat untuk bayi pada usia ini. ASI eklusif menurut World Health Organization (WHO), (2016) adalah pemberian ASI saja tanpa tambahan cairan lain baik susu formula, air putih, air jeruk, ataupun makanan tambahan lain. Sebelum mencapai usia 6 bulan sistem pencernaan bayi belum mampu berfungsi dengan sempurna, sehingga ia belum mampu mencerna makanan selain ASI.

b. Gizi Bayi Usia 9 - 12 Bulan,

Bayi usia 9 bulan merupakan usia peralihan kedua dalam pengaturan makanan bayi. Makanan bayi yang tadinya bertumpu pada ASI sebagai pemberi zat gizi utama, setelah usia 9 bulan akan beralih ke makanan sapihan sebagai pemberi zat gizi utama, sedangkan ASI hanya berperan sebagai pelengkap. Pada usia 9 bulan kebutuhan kalori bayi adalah 350 kal (dari $500 \mathrm{ml} \mathrm{ASI).}$ Sehingga diperlukan tambahan makanan sebesar 450-500 kalori per hari. Masalah dalam menyusun makanan tambahan untuk bayi usia ini adalah bagaimana menyusun makanan tersebut sehingga memenuhi kebutuhan bayi akan zat gizi, dengan mutu yang mendekati mutu gizi ASI.

\section{Kebutuhan Gizi Anak}

Beberapa hal yang perlu diperhatikan dan menjadi perbedaan dewasa dengan balita dalam hal kebutuhan gizi adalah Gula \& Garam,- lupakan penggunaan gula dan garam pada menu bayi. 
Kalau pun ia sudah berusia di atas 1 tahun, batasi penggunaannya. Konsumsi garam untuk balita tidak lebih dari 1/6 jumlah maksimum orang dewasa sehari atau kurang dari 1 gram. Cermati makanan balita Ibu karena makanan orang dewasa belum tentu cocok untuknya. Kadang makanan Ibu terlalu banyak garam atau gula, atau bahkan mengandung bahan pengawet atau pewarna buatan. Berikutnya adalah Porsi Makan - Porsi makan anak juga berbeda dengan orang dewasa. Mereka membutuhkan makanan sumber energi yang lengkap gizi dalam jumlah lebih kecil namun sering. Selanjutnya yaitu Kebutuhan Energi \& Nutrisi - Bahan makanan sumber energi seperti karbohidrat,protein, lemak serta vitamin, mineral dan serat wajib dikonsumsi anak setiap hari. Atur agar semua sumber gizi tersebut ada dalam menu sehari. Terakhir adalah Susu Pertumbuhan - Susu sebagai salah satu sumber kalsium, juga penting dikonsumsi balita. Sedikitnya balita butuh $350 \mathrm{ml} / 12$ oz per hari.

\section{Gizi Pada Anak Usia Sekolah}

1. Pola makan anak usia Taman Kanak-kanak (4-6 tahun) Anak sudah mempunyai sifat konsumen aktif, yaitu mereka sudah sudah bisa memilih makanan yang disukainya. Perlu ditanamkan kebiasaan makan dengan gizi yang baik pada usia dini dan di sekolah diarahkan pula oleh gurunya dengan praktik mengkonsumsi makanan yang sehat secara rutin. Program makan bersama di sekolah sangat baik dilaksanakan karena ini merupakan modal dasar bagi pengertian anak supaya mereka mau diarahkan pada pola makan dengan gizi yang baik .

2. Pada usia 7-9 tahun anak pandai menentukan makanan yang disukai karena sudah kenal lingkungan. Banyak anak menyukai makanan jajanan yang dapat mengurangi nafsu makan anak. Perlu pengawasan supaya tidak salah memilih makanan karena pengaruh lingkungan.

3. Pada anak usia 10-12 tahun kebutuhan sudah dibagi dalam jenis kelaminnya: Anak laki-laki lebih banyak aktivitas fisik sehingga memerlukan energi yang banyak dibandingkan anak perempuan. Anak perempuan sudah mengalami masa haid sehingga lebih banyak banyak protein, zat besi dari usia sebelumnya. Perlu diperhatikan pula adalah pentingnya sarapan pagi supaya konsentrasi belajar tidak terganggu.

\section{Kebutuhan Gizi Remaja}

kebutuhan gizi remaja, energi sangat diperlukan dalam jumlah banyak untuk pertumbuhan dan aktivitas yang memasuki periode tumbuh cepat. Kebutuhan energi pada remaja dipengaruhi oleh energi basal, jenis kelamin, faktor aktivitas, dan adanya penyakit. Semua kebutuhan zat gizi meningkat pada masa remaja. Jumlah zat gizi yang dibutuhkan ini disesuaikan dengan daftar Angka Kecukupan Gizi (AKG). Protein; seimbang (1gr/kgBB/hr). Mineral Fe \& Ca kebutuhannya 800-1200 mg/hr . Kebutuhan gizi harus sehat dan seimbang. Makanan harus cukup semua zat gizi. Masalah gizi meliputi ; pengetahuan tentang gizi yang relatif masih kurang; aktifitas fisik yang tinggi; Pola makan yang tidak teratur; defisiensi besi karena mulai menstruasi pada putri; dan obesitas . 


\section{Kebutuhan Gizi Dewasa}

Kebutuhan kalori mulai berkurang pada usia 25 tahun, tergantung pada aktivitas fisik, jenis kelamin, dan massa tubuh. Zat besi dibutuhkan oleh usia subur selama masa reproduksi, untuk menggantikan kehilangan zat besi selama menstruasi, kehamilan, kelahiran dan menyusui, kalsium juga berperan penting untuk pertulangan, mengingat kehilangan kalsium dalam massa tulang berkurang pada masa usia lanjut. Kebiasaan minum susu atau makan bahan makanan sumber kalsium cukup dianjurkan pada usia dewasa. Pengaturan makanan yang baik : makan makanan rendah lemak, makan rendah kolesterol; makan lebih banyak serat : buah, sayur, dan kacang-kacangan; makan lebih banyak karbohidrat kompleks : biji-bijian, kacang-kacangan, dan sayuran; hindari alcohol; baca label makanan, dan kurangi konsumsi gula. Masalah gizi pada usia dewasa meliputi : Kurang Energi Protein (KKP), Anemia pada wanita dan masalah Gizi lebih/Obesitas. Gizi lebh ini disebabkan adanya kecenderungan masyarakat untuk memilih makanan yang tinggi kalori dan lemak tetapi rendah serat terutama karena meningkatnya status ekonomi , faktor gaya hidup yg kurang gerak /aktivitas juga menyebabkan penimbunan lemak tubuh yang mengarah pada kegemukan

Prinsip gizi seimbang dewasa : Tubuh manusia membutuhkan aneka ragam makanan yang dijamin mengandung sumber karbohidrat (nasi, roti, kentang, mie, singkong, dll), protein hewani/nabati (ikan, telur, daging, ayam, tempe, tahu, kacang-kacangan), vitamin dan mineral ( buah-buahan, sayuran), dan sumber lemak/minyak (minyak goreng, santan, mentega, margarin) dan air .

\section{Kebutuhan Gizi Lansia}

penelitian menunjukan bahwa kecepatan metabolisme basal pada orang-orang berusia lanjut menurun sekitar $15-20 \%$, disebabkan berkurangnya massa otot dan aktivitas. Kalori (energi) diperoleh dari lemak 9,4 kal, karbohidrat $4 \mathrm{kal}$, dan protein 4 kal per gramnya. Bagi lansia komposisi energi sebaiknya $20-25 \%$ berasal dari protein, $20 \%$ dari lemak, dan sisanya dari karbohidrat. Kebutuhan kalori untuk lansia laki-laki sebanyak 1960 kal, sedangkan untuk lansia wanita 1700 kal. Bila jumlah kalori yang dikonsumsi berlebihan, maka sebagian energi akan disimpan berupa lemak, sehingga akan timbul obesitas. Sebaliknya, bila terlalu sedikit, maka cadangan energi tubuh akan digunakan, sehingga tubuh akan menjadi kurus.

- Kebutuhan Karbohidrat dan Serat Makanan.

Salah satu masalah yang banyak diderita para lansia adalah sembelit atau konstipasi (susah buang air besar) dan terbentuknya benjolan-benjolan pada usus. Serat makanan telah terbukti dapat menyembuhkan kesulitan tersebut. Sumber serat yang baik bagi lansia adalah sayuran, buah-buahan segar dan biji-bijian utuh. Manula tidak dianjurkan mengonsumsi suplemen serat (yang dijual secara komersial), karena dikuatirkan konsumsi seratnya terlalu banyak, yang dapat menyebabkan mineral dan zat gizi lain terserap oleh serat sehingga tidak dapat diserap tubuh. 
Lansia dianjurkan untuk mengurangi konsumsi gula-gula sederhana dan menggantinya dengan karbohidrat kompleks, yang berasal dari kacang-kacangan dan biji bijian yang berfungsi sebagai sumber energi .

\section{- Kebutuhan Protein}

Secara umum kebutuhan protein bagi orang dewasa per hari adalah 1 gram per kg berat badan Pada lansia, massa ototnya berkurang. Tetapi ternyata kebutuhan tubuhnya akan protein tidak berkurang, bahkan harus lebih tinggi dari orang dewasa, karena pada lansia efisiensi penggunaan senyawa nitrogen (protein) oleh tubuh telah berkurang (disebabkan pencernaan dan penyerapannya kurang efisien). Beberapa penelitian merekomendasikan, untuk lansia sebaiknya konsumsi proteinnya ditingkatkan sebesar $12-14 \%$ dari porsi untuk orang dewasa. Sumber protein yang baik diantaranya adalah pangan hewani dan kacang-kacangan.

- Kebutuhan Lemak

Konsumsi lemak yang dianjurkan adalah 30\% atau kurang dari total kalori yang dibutuhkan. Konsumsi lemak total yang terlalu tinggi (lebih dari $40 \%$ dari konsumsi energi) dapat menimbulkan penyakit atherosclerosis (penyumbatan pembuluh darah ke jantung). Juga dianjurkan $20 \%$ dari konsumsi lemak tersebut adalah asam lemak tidak jenuh (PUFA = poly unsaturated faty acid). Minyak nabati merupakan sumber asam lemak tidak jenuh yang baik.

- Kebutuhan Vitamin dan Mineral

Hasil penelitian menyimpulkan bahwa umumnya lansia kurang mengonsumsi vitamin $A, B 1, B 2$, B6, niasin, asam folat, vitamin C, D, dan E umumnya kekurangan ini terutama disebabkan dibatasinya konsumsi makanan, khususnya buah-buahan dan sayuran, serta kemampuan fisik yang menurun. Kekurangan mineral yang paling banyak diderita lansia adalah kurang mineral kalsium yang menyebabkan kerapuhan tulang dan kekurangan zat besi menyebabkan anemia. Kebutuhan vitamin dan mineral bagi lansia menjadi penting untuk membantu metabolisme zatzat gizi yang lain. Sayuran dan buah hendaknya dikonsumsi secara teratur sebagai sumber vitamin, mineral dan serat. Masalah pada lansia penurunan sekresi asam lambung dan enzim pencerna makanan, hal ini mengganggu penyerapan vitamin dan mineral, akibatnya lansia menjadi defisiensi zat-zat gizi mikro. Mobilitas usus menurun, mengakibatkan susah buang air besar, sehingga lansia menderita wasir yang bisa menimbulkan perdarahan dan memicu terjadinya anemia . 


\section{DAFTAR PUSTAKA}

http://bppsdmk.kemkes.go.id/pusdiksdmk/wp-content/uploads/2017/08/Ilmu-GiziKeperawatan-Komprehensif.pdf

http://repositori.uin-alauddin.ac.id/17794/

http://repository.unp.ac.id/1127/1/ANTON\%20KOMAINI_113_11.pdf

http://eprints.poltekkesjogja.ac.id/1333/4/Chapter\%202.pdf

http://hukor.kemkes.go.id/uploads/produk_hukum/PMK_No_28_Th_2019_ttg_Angka_Kecukup an_Gizi_Yang_Dianjurkan_Untuk_Masyarakat_Indonesia.pdf 